\begin{tabular}{ccc}
\hline Sournals & $\begin{array}{c}\text { INTERNATIONAL JOURNAL OF } \\
\text { ORGANIZATIONAL LEADERSHIP }\end{array}$ & $\begin{array}{c}\text { INDUSTRIAL } \\
\text { MANAGEMENT } \\
\text { INSTITUTE }\end{array}$ \\
\hline \hline
\end{tabular}

\title{
Authentic Leadership: A New Approach to Leadership (Describing the Mediatory Role of Psychological Capital in the Relationship between Authentic Leadership and Intentional Organizational Forgetting)
}

\author{
Samaneh Mohammadpour', Nour Mohammad Yaghoubi ${ }^{2 *}$, Amin Reza Kamalian ${ }^{3}$, \\ Habibollah Salarzehi ${ }^{3}$ \\ ${ }^{1}$ PhD student of Public Administration, University of Sistan and Baluchestan, Zahedzan, Iran \\ 2 Full Professor of Public Administration, University of Sistan and Baluchestan, Zahedan, Iran \\ 3 Associate Professor of Public Administration, University of Sistan and Baluchestan, Zahedan, Iran
}

\section{Keywords: \\ Authentic Leadership, Intentional Organizational Forgetting, Psychological Capital}

\section{Received}

06 February 2017

Received in revised form 25 November 2017

Accepted

05 December 2017

Correspondence:

yaghoobi@hamoon.usb.ac.ir

\begin{abstract}
In the last decade, companies have increasingly understood the value of knowledge management for obtaining competitive advantage. The two main dimensions of knowledge management are organizational learning and organizational forgetting. Despite much research that has been done about knowledge management and organizational learning, not much studies have been conducted so far on organizational forgetting and how to handle it. The purpose of the present study is to consider the relationship between the most recent leadership approach called authentic leadership and the concept of intentional organizational forgetting and psychological capital, which are suggested as a conceptual model for the first time. Research methodology is descriptive-correlational, and in terms of purpose, it is an applied study. Statistical population includes the employees of National Oil Products Distribution Company of Sistan and Baluchestan Province, out of which 165 individuals were selected through random sampling. Data collection tool includes the standard questionnaires of authentic leadership, organizational forgetting, and psychological capital, whose content validity was confirmed by experts' comments and its reliability was confirmed by Cronbach's alpha. In this research, correlation test, regression test, and structural equations model were used, and data were analyzed using LISREL Software. Results indicate that authentic leadership directly and indirectly affects intentional organizational forgetting through psychological capital. Also, the psychological capital, as a mediator variable, is relatively effective in the relationship between authentic leadership and intentional organizational forgetting.
\end{abstract}


As one of the most important organizational components, knowledge management requires establishing a system for learning, gathering, maintaining, and distributing knowledge inside the organization. In addition to promoting organizational learning, this system should be able to prevent the forgetting of the necessary and useful knowledge on one hand, and to put away the useless knowledge on the other hand. Despite the need to develop organizational learning capabilities, studies have shown that organizations do not always learn something easily.

Conklin (2001) states that organizations instinctively tend to forget. Forgetting the information, techniques, and valuable knowledge by organizations can result in the loss of competitive advantages. However, in some cases, organizational forgetting increases competition and eliminates useless knowledge elements (Martin De Holan, Phillips, \& Lawrence, 2004). It seems that this phenomenon is an essential process in change management (Fernandez \& Sune, 2009). Today Oil and Gas Industry struggles with conditions such as insufficient number of experienced applicants for entering this industry, lack of full awareness about industry, low absorption in industry, old experienced personnel, and keeping knowledge in individuals' mind and not sharing it. Managers' leadership style is one of the factors affecting the increase of efficiency, effectiveness, and ultimately productivity of organizations. Among the new theories that have been proposed for inspiring and employing the psychological capacity of staffs, we can refer to the theory of Authentic Leadership.

Authentic Leadership theory is the most recent and complete leadership approach which has been proposed in recent years. Authentic leaders are those who have gained self-knowledge and are aware of their thoughts and behaviours. They are confident, hopeful, optimistic, and very moralist (Gardner, Cogliser, Davis, \& Dickens, 2011). This leadership style is formulated based on the combination of transformational and ethical leadership styles and is derived from the process of positive mental capacity and the concept of organizational excellence, which lead to managers' self-awareness and self-regulation (Algera \& Lips-Wiersma, 2012).

Authentic leadership is the behavioural pattern that not only has positive psychological capacities, but also it can reinforce these positive psychological capacities in staffs (Walumbwa, Avolio, Gardner, Wernsing, \& Peterson, 2008). Research has shown that staffs who are led by authentic leaders have higher psychological capital and this psychological resource encourages them to be more creative (Rego, Sousa, Marques, \& Pina e Cunha, 2012). Reliable leaders bring about conditions that improve confidence and self-confidence in carrying out career tasks that in turn leads to improvement in personal and organizational performance (Laschinger \& Fida, 2014).

Much research has been done about authentic leadership, which indicates its effect on organizational factors such as performance, organizational citizenship behaviour, human resource empowerment, trust to management, organizational commitment, emotional intelligence, and organizational learning (Kara, Uysal, Sirgy, \& Lee, 2013; Wong \& Laschinger, 2012). Moreover, further research and study shows lack of research about its effect on organizational forgetting.

On the other hand, despite much research that has been done about knowledge management and organizational learning, organizational forgetting and its management have not been comprehensively studied so far. The novelty of this research is that it has been formulated based on this theoretical gap. The purpose of this paper is to consider the relationship between 
authentic leadership and intentional organizational forgetting and psychological capital in the National Oil Products Distribution Company of Sistan and Baluchestan Province. In this paper, after having a brief look upon the theoretical fundamentals and the literature according to the conceptual model and research hypotheses, method, and data analysis are considered using structural equations model.

\section{Authentic leadership}

The need of society to a leader and the importance of his performance is not a secret. An effective leader in the organization is the main factor in creating sympathy and empathy. Over the past hundred years, leadership theories have emerged worldwide (Waite, Mckinney, Glasgow, \& Meloy, 2014), but authentic leadership theory is still in the nascent stage of development (Hinojosa et al., 2014). Authentic Leadership theory is the last one which has been operated (Avolio \& Gardner, 2005; Brown \& Trevino, 2006; Toor \& Ofori, 2007). Authentic leadership theory is a normative theory that describes an ideal leader for organizations whose aim is to integrate basic ideas about effective leadership in connection with ethical leadership (Joo \& Nimon, 2014). Avolio and Gardner proposed the Authentic Leadership theory in 2005. Authentic leadership is a behavioural pattern derived from positive psychological capacities and organizational positive moral atmosphere and leads to promoting self-awareness, internalized moral perspectives, balanced information processing, and relational transparency in working with followers (Walumbwa et al., 2008). Identifying features such as tendency to adjust one's own behavior, performance without bias or prejudice in the decision-making, and having open and honest professional relationships are signs of authentic leadership (Stoten, 2014). Authentic leadership dimensions include self-awareness, balanced processing, internalized moral perspectives, and relational transparency.

Self-awareness is the most important element and the essential cornerstone of authentic leadership, which refers to understanding personal strengths and weaknesses and how to interact with the surrounding environment. Authentic leaders are strongly aware of their values, emotions, goals, motivations, and strengths and weaknesses (Alok, 2014). In Avolio and Gardner's study (2005), self-awareness includes four elements, namely values, cognitive identity, feelings, and objectives/incentives. In fact, regardless of self-awareness, authenticity will be more related to the relevance between personal identity and performance (Diddams \& Chang, 2012).

Balanced processing includes the analysis of all related information before taking any decision. Leaders who seek after others' viewpoints and comments and challenge the existing conditions have this feature (Neider \& Schriesheim, 2011).

Internalized moral perspectives refer to behaviours that are led by values and moral criteria internalized in the individual, rather than by external pressures such as colleagues, organization, and society (Peterson, Walumbwa, Avolio, \& Hannah, 2012).

Relational transparency refers to close relations with high levels of self-disclosure and trust and shows the extent to which the leader reinforces an open and transparent relationship with others in order to provide the opportunity of enjoying opinions, comments, and challenges in near future. In this case, by developing positive traits such as optimism, hope, and self- 
confidence, the leader helps to create such relationships and makes him and his followers grow (Furmanczyk, 2010).

\section{Organizational Forgetting}

The concept of organizational forgetting was first introduced by Hedberg through referring to this point that organizations can put their knowledge away intentionally. He stated that organizations should intentionally put away their existing and useless knowledge, and if they do not do so, their survivability will be at risk. Although he does not directly point to organizational forgetting, he refers to two aspects of forgetting, namely intentional and accidental. In the former, the organizational puts knowledge away intentionally (purposefully) and in the latter, the organization loses knowledge accidentally (Hedberg, 1981). Instead of discussing how knowledge is lost, Martin De Holan and Phillips (2003) focus on producing, transferring, and eliminating it intentionally from the organizational memory. They believe that forgetting (meaning to forget the existing knowledge so as to provide a new space for capturing new knowledge) occurs before, during, and after learning processes (Martin De Holan et al., 2004). In order to describe organizational forgetting, Martin De Holan et al. (2004) intends to establish relation between the mode of forgetting and the type of the forgotten knowledge. The first dimension shows the difference between intentional and accidental forgetting and the second dimension refers to the source of knowledge. In many cases, the organization intentionally and accidentally forgets the existing knowledge and skills and sometimes the newly innovated knowledge. His theory about organizational forgetting is presented in Figure 1 (Martin De Holan et al., 2004).

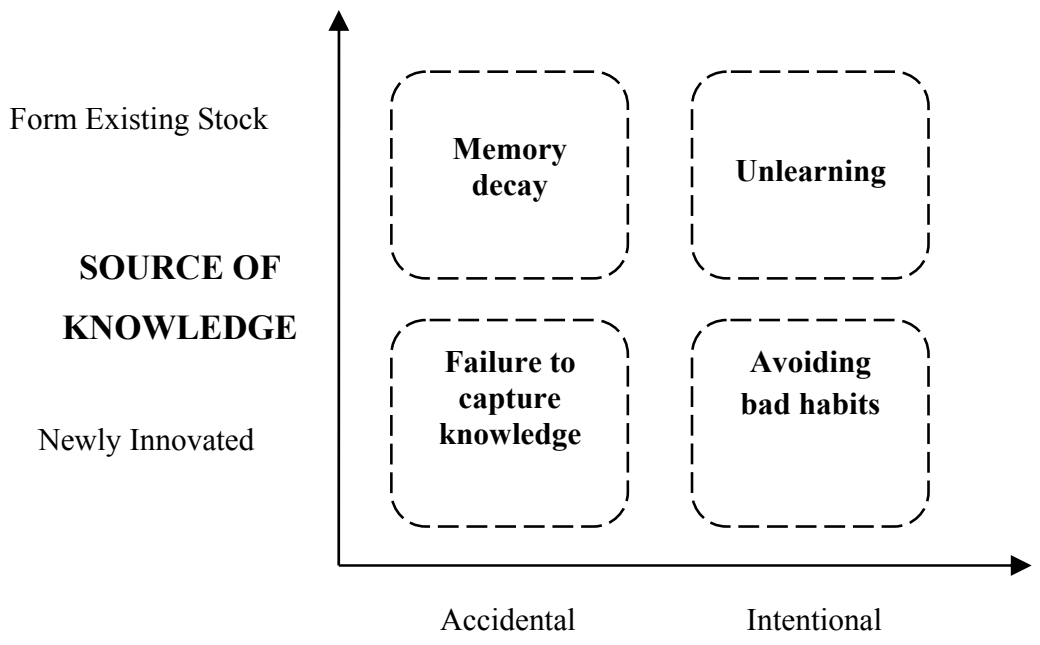

MODE OF FIRGETIN

Figure 1. Forms of organizational forgetting (Martin De Holan et al., 2004)

In the following, Martin De Holan's (2004) classification of organizational forgetting is explained:

Memory decay: In this type of organizational forgetting, the organization forgets the existing and available knowledge accidentally. Memory decay causes the organization to lose 
its important competitive advantages and incurs many costs for reproducing the forgotten knowledge.

Failure to capture knowledge: Failure to capture knowledge occurs when the organization cannot maintain the newly innovated knowledge and loses it unpredictably. In this case, the organization is ignorant of making the new and valuable information available for others.

Unlearning: Unlearning can be as important as learning for the organization. An organization attempts to put away the information and knowledge which may damage its success.

Avoiding bad habits: Like individuals, organizations can also learn indecent habits, instructions, actions, beliefs, and values that are harmful for production. Successful organizations are able to intentionally forget such knowledge before they are stabilized and internalized in the organizational memory (Martin De Holan et al., 2004).

\section{Psychological Capital}

The concept of psychological capital is rooted in Seligman's works (1998). He is known as the Father of Positive Psychology (Hodges, 2010). Psychological capital is one of the indices of positive psychology, which is characterized by the individual's belief in his abilities to achieve success, having perseverance in pursing objectives, creating positive attributes about him, and tolerating problems (Avey, Patera, \& West, 2006). In the present paper, Luthans model (2002) was used for the variable "psychological capital". Based on this model, psychological capital components are self-efficacy, hope, optimism, and resiliency.

Self-efficacy / self-confidence: This term is defined as "the individual's belief or confidence in his abilities to achieve success in doing a certain task through motivating himself, providing cognitive resources for himself, and taking the necessary actions" (Luthans, 2002).

Hope: Snyder, Irving, and Anderson (1991) have defined hope as a positive motivational state which results from an interactional feeling derived from two factors, namely goal-oriented energy and planning for success. Therefore, hope requires functionality or a kind of energy for pursuing goals. Moreover, the other constituting component of hope is to plan for success, which includes not only the identification of goals, but also the different ways of achieving them (ibid.).

Optimism: Optimism refers to the overall evaluation of expected results. Seligman (1998) defines optimism as an interpretive (descriptive) style which attributes positive events to continuous, personal, and comprehensive reasons and negative events to external, transient, and particular reasons.

Flexibility / resiliency: This concept is defined as the ability to refer to intellect or return to the conditions before misery, conflict, failure, or even positive events, progress and increased responsibilities. After encountering difficult situations in life, resilient individuals return to the normal level of performance, while some other individuals' performance is enhanced after facing with fiasco, disaster, and difficulty (Luthans, 2002).

Review of literature and research indicates that there has been no study with the subject of the present study, but any of the variables of the study have been studied in some way with each other. In this section, some of the related conducted studies are mentioned. 
Wang et al. (2014) considered the effect of the mediator role of followers' psychological capital and the mediator role of interactions between the leader and members in influencing the relationship between authentic leadership and followers' performance. The results of their study showed that authentic leadership has a positive relationship with interactions between the leader and members and consequently with the staffs' performance in large scale among those followers who have got lower psychological capital.

Laschingera \& Fida (2014) showed the significant relationship between authentic leadership and psychological capital as well as the supportive role of organizational and intrapersonal resources in confronting with occupational burnout, job dissatisfaction, and mental health. In a study, Rego et al. (2012) showed a positive significant relationship between authentic leadership and creativity, and the effect of psychological capital on this relationship. Yammarino, Dionne, Schriesheim, and Dansereau (2008) considered the relationship between authentic leadership and positive psychological capital and indicated that authentic leadership potentially affects the positive psychological capabilities such as psychological capital. Moreover, the results obtained from Clapp-Smith, Vogelgesang, and Avey's study (2009) showed that trust to manager plays a mediator role in the relationship between psychological capital and performance. It also plays a positive mediator role in the relationship between authentic leadership and performance. In their study, TaghvaiYazdi (2015) showed that there is a significant positive relationship between transformational leadership style and targeted organizational forgetting as well as between transformational leadership style and organizational learning from the staff perspective. Moreover, in a similar study, Azizinejad, Jenabadi, and Moradzadeh (2011) concluded that leadership styles (transformational and exchange) have direct and significant impact on the organizational targeted forgetting and organizational performance and leadership style through targeted organizational forgetting has an indirect impact on organizational performance.

Moshabaki and Rabia (2007) showed the existence of a significant relationship between the dimensions of purposeful forgetting (new knowledge and existing knowledge) and charismatic leadership. In another study, Moshabaki, Andalib Ardakani, and Andalib Ardakani (2011) concluded that despite the more impact of transformational leadership style, both transformational and pragmatic leadership styles have an effect on organizational targeted forgetting. In a research, Hsiao \& Chang (2011) showed the positive significant relationship between transformational leadership and organizational innovation as well as the mediator role of organizational learning in this relationship. In their research, Zeng \& Chen (2010) investigated the relationship between intentional organizational forgetting, organizational learning capability, and organizational innovation and showed that intentional organizational forgetting directly and indirectly affects organizational innovation, and organizational learning capability plays the role of a mediator variable in their relationship. In sum, the present paper attempts to more investigate organizational forgetting which has been less addressed as a latent factor. It also intends to study its conceptual model by taking into account the authentic leadership style as a factor affecting organizational forgetting and psychological capital.

\section{The Study}

In codifying the conceptual model of the research, several models are used which include 
Avolio et al.'s Authentic Leadership Model (2004), Luthans' Psychological Capital Model (2002) and Martin De Holan et al.'s Organizational Forgetting Model (2004). Therefore, according to the literature, the conceptual model of the research is as follows:

$\mathrm{H}_{4}$

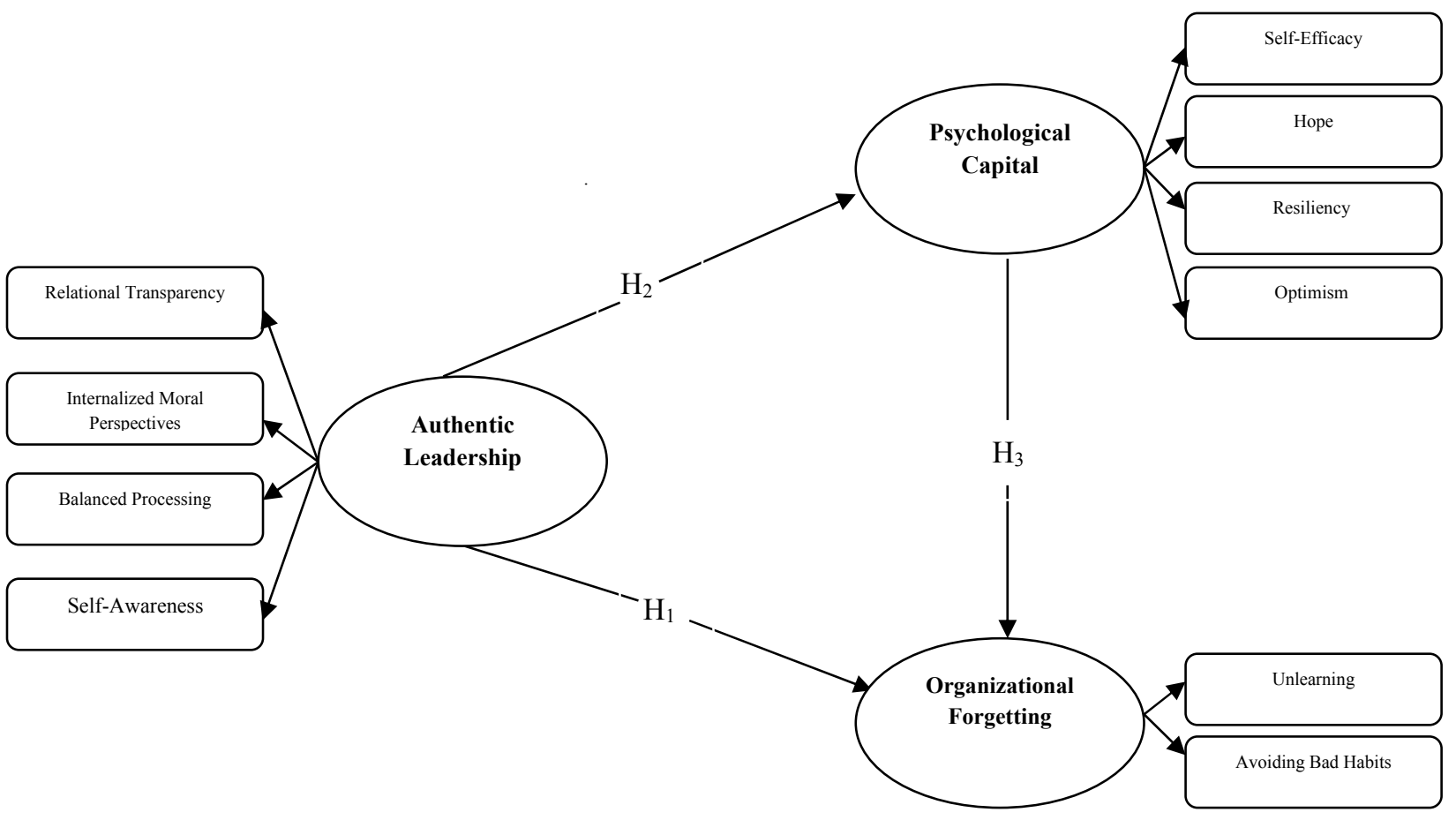

Figure 2. Conceptual model

\section{Research Hypothesis}

Based on the conceptual model, research hypotheses are as follows:

$\mathbf{H}_{1}$ : Authentic leadership has positive effect on intentional organizational forgetting.

$\mathbf{H}_{2}$ : Psychological capital has positive effect on intentional organizational forgetting.

$\mathbf{H}_{3}$ : Authentic leadership has positive effect on psychological capital.

$\mathbf{H}_{4}$ : Psychological capital has positive effect on the relationship between authentic leadership and intentional organizational forgetting.

\section{Method}

In terms of purpose, this is an applied study and in terms of data collection, it is a descriptivesurvey research. Statistical population of the research includes the staffs of National Oil Products Distribution Company of Sistan and Baluchestan Province, who were 294 individuals at the time of conducting this research. In this paper, Morgan's table is used to determine the sample size and it was estimated as 165 individuals. The main measurement tool is questionnaire which includes standard questionnaires of Avolio and Gardner's Authentic Leadership (2005), Martin De Holan et al.'s Organizational Forgetting (2004) and Luthans, Avolio, Avey, and Norman's Psychological Capital (2007). After making some changes in 
them in order to make them proportionate with the statistical population and asking the experts' opinions, these questionnaires were used to measure the validity of questions. To analyze the research data, in the first stage, reliability of questions was calculated using Cronbach's alpha test and it was obtained as 0.90 for authentic leadership items, 0.81 for organizational forgetting, and 0.83 for psychological capital. This shows a suitable and acceptable reliability for the questionnaire. Data normality was considered using Kolmogorov-Smirnov test. In the next stage, the relationship between the variables was considered using the correlation test, and finally the research hypotheses were tested using structural equations modeling. In this paper, suitable fitting indices of the model include $\mathrm{X}^{2}$ (chi-square), NFI (Bentler-Bont index), NNFI (Tucker-Lewis index), GFI (goodness of fit index), AGFI (adjusted goodness of fit index), CFI (comparative fit index), and RMSEA (the root mean square error of approximation). Data were analyzed using LISREL 8/5 Statistical Software.

\section{Results}

Consideration of the demographic findings of this research shows that $73.9 \%$ of respondents were men and $26.1 \%$ were women. About 12.7 of respondents were aged under 30 years, $75.2 \%$ between 30 and 40 years, $7.9 \%$ between 40 and 50 years, and $4.2 \%$ were more than 50 years. Moreover, $8.5 \%$ had a high school diploma, 15.8\% had associate's degree, $60 \%$ had a bachelor's degree, and $15.8 \%$ possessed master's degree. Following this, $3.6 \%$ of the respondents had less than 5 years of service, $49.7 \%$ between 5 and 10 years, $32.7 \%$ between 10 and 15 years, $7.3 \%$ between 15 and 20 years, and $6.7 \%$ had 20 years of work experience.

In order to consider the relationship between variables, Pearson's correlation test was first used, and if a correlation was established between variables, then structural equations modeling was used to test causal relationships. The results obtained from correlation test shows that authentic leadership has a significant correlation with intentional organizational forgetting and psychological capital. Moreover, there is a significant positive correlation between the two variables of psychological capital and intentional organizational forgetting. Table1 presents the results of this test.

Table 1

Correlation Matrix for Research Variables

\begin{tabular}{|c|c|c|c|c|c|}
\hline Research Variables & Authentic Leadership & Organizational Forgetting & Mean & Std. Deviation & Cronbach's Alpha \\
\hline Authentic Leadership & -- & & 4.47 & 0.65 & 0.90 \\
\hline Organizational Forgetting & $0.53 * *$ & -- & 3.65 & 0.49 & 0.81 \\
\hline Psychological Capital & $0.63 * *$ & $0.44 * *$ & 3.92 & 0.36 & 0.83 \\
\hline
\end{tabular}

** Correlation is significant at level 0.001

\section{Consideration of Structural Equations Model}

In this section, the relationship between internal and external latent variables is considered. Here the purpose is to find that whether the theoretical relationships which were realized among variables when codifying the intended theoretical framework are confirmed by data or not. Also, in order to measure the role of the mediator variable, Baron and Kenny's instruction (1986) was used. They believe that to measure the effect of the mediator variable, three steps 
are required: Step one) to show a significant relationship between the independent variable(s) and dependent variable; step two) to show a significant relationship between the independent variable(s) and mediator variable; and step three) to measure the simultaneous effect of the independent variable and mediator variables on the dependent variable in a single model. Therefore, the presented model was measured with and without taking into account the direct effect of the independent variable on dependent variable. In the second model, by entering the mediator variable, if the relationship between the independent variable and dependent variable is not significant ( $t$ in the interval $(-1.96,1.96)$ ), then the effect of the mediator variable is complete. However, if there is still a significant relationship between the two variables, the effect of the mediator variable is relative.

Table 2 presents the direct effect of the independent variable on dependent variable.

Table 2

Direct Effect of the Independent Variable on Dependent Variable

\begin{tabular}{ccc}
\hline & Path Coefficient & t-Statistics \\
\hline Authentic Leadership $\longrightarrow$ Organizational Forgetting & 0.61 & 6.28 \\
\hline
\end{tabular}

Model 2: Without taking into account the direct effect of the independent variable on dependent variable.

Confirmatory factor analysis and path diagrams (standard weights and coefficients significance) of the research conceptual model are shown in Figure 3 and 4.

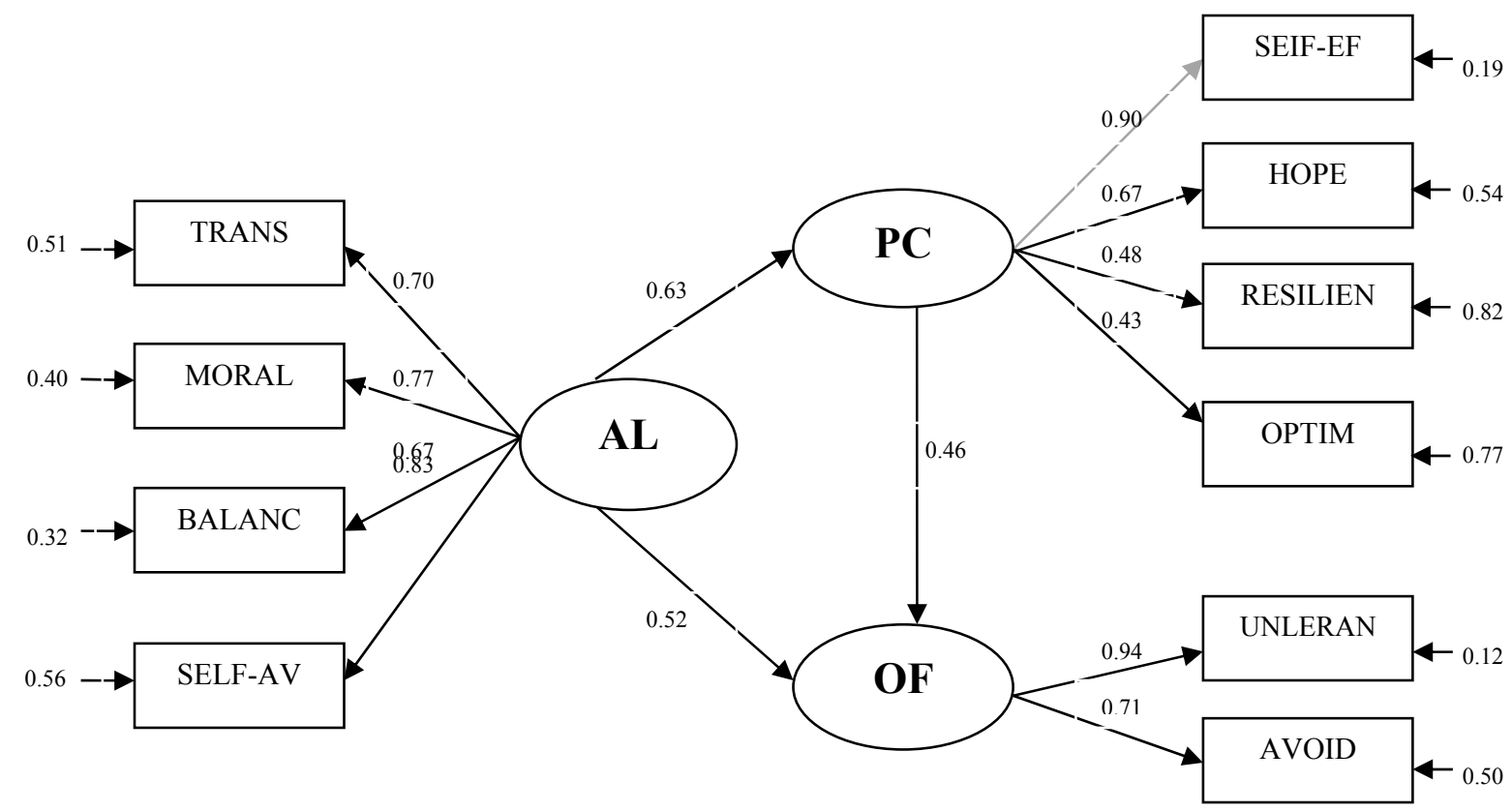

Figure 3. Structural equations modeling of the research conceptual model (standard approximation) 


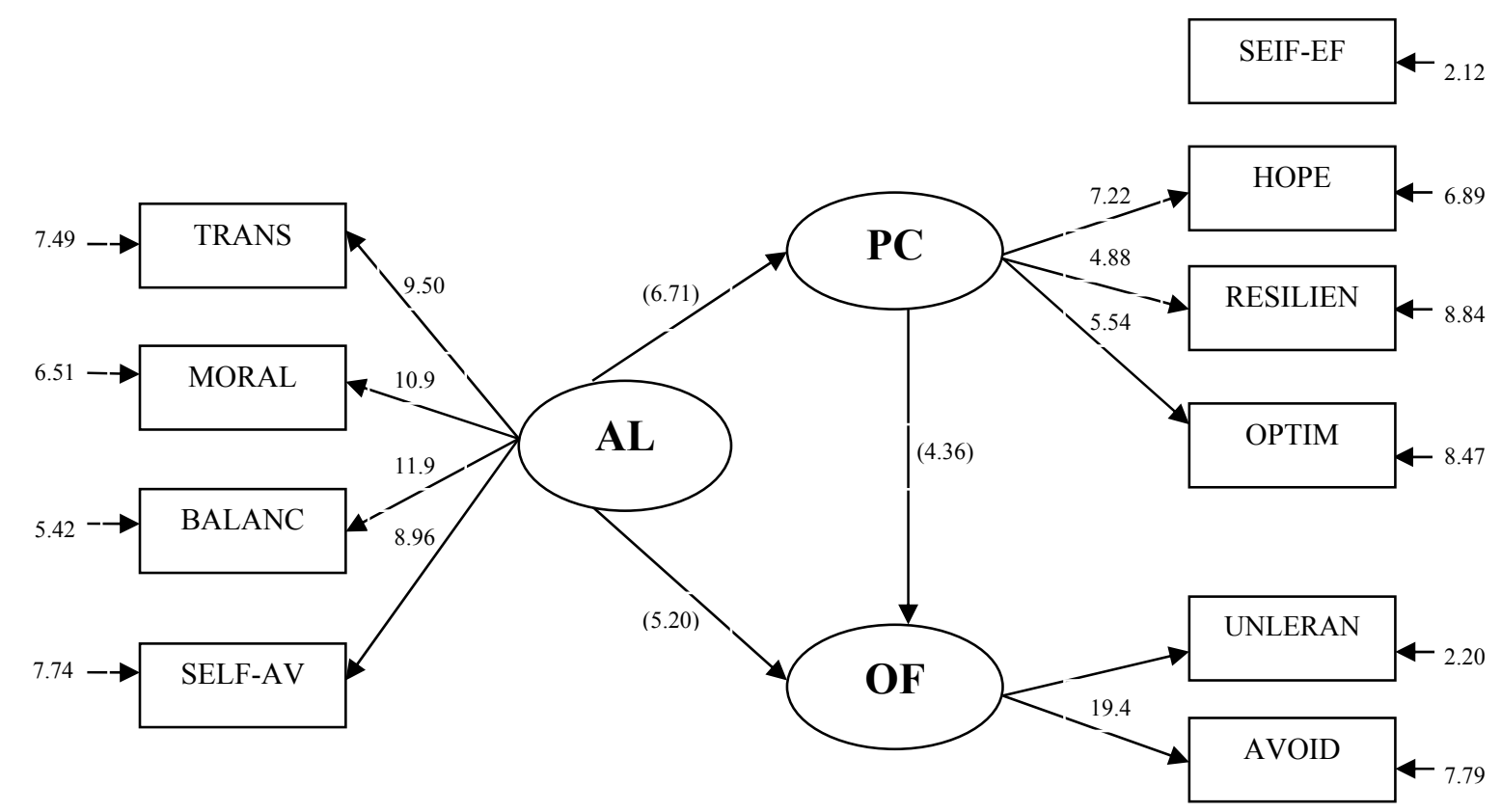

Figure 4. Structural equations modeling of the research conceptual model (coefficients significance)

As can be seen in structural function pattern in Figure 3, the model is in a desirable status, so that authentic leadership and psychological capital with coefficients 0.52 and 0.46 have direct, positive, and significant effect on organizational forgetting (the first and second hypotheses). Also, the coefficient 0.63 indicates the direct, positive, and significant effect of authentic leadership on staffs' psychological capital (the third hypothesis). Figure 4 shows the significance numbers for the proposed relationships. Given the T-value, authentic leadership has a significant relationship with intentional organizational forgetting $(\mathrm{T}=5.20)$ and psychological capital $(\mathrm{T}=6.71)$. Moreover, the model shows a significant relationship between psychological capital and intentional organizational forgetting $(\mathrm{T}=4.36)$. Therefore, hypotheses 1, 2, and 3 are confirmed. According to Figure 5, in the second model (indirect measurement of the effect of the independent variable on dependent variable) it is observed that, according to the role of the mediator variable, the path coefficient value between the independent and dependent variables has decreased from 0.61 to 0.52 . Therefore, the variable of psychological capital has a relative effect on the relationship between authentic leadership and intentional organizational forgetting; hence the fourth hypothesis is confirmed. Table 3 exhibits the fit indices of the research conceptual model.

Table 3

Fitting Indices of the Research Conceptual Model

\begin{tabular}{|c|c|c|c|c|c|c|c|}
\hline Fitting Indices & $\mathrm{X}^{2} / \mathrm{df}$ & NFI & NNFI & CFI & GFI & AGFI & RMSEA \\
\hline Model Values & 1.67 & 0.96 & 0.95 & 0.97 & 0.94 & 0.92 & 0.052 \\
\hline Allowed Values & $\begin{array}{c}3 \text { and } \\
\text { Less }\end{array}$ & 0.9 and More & 0.9 and More & 0.9 and More & 0.9 and More & 0.9 and More & Less than 0.08 \\
\hline
\end{tabular}

A model has suitable fit if its ratio of $\mathrm{X}^{2}$ to degree of freedom (DF) is less than 3; NFI, 
NNFI, CFI, GFI, and AGFI values are more than 0.9 and RMSEA is less than 0.08. Also, if the significance number ( $\mathrm{T}$-value) is more than 1.96 or less than -1.96 , then the existing relationship in the research model is significant. As can be seen in the table, values of all indices indicate suitable and acceptable fit of the research conceptual model; therefore, based on the fit of the research conceptual model, the conformance of the conceptual model with the collected data is confirmed. Table 4 shows the results of regression analysis.

Table 4

Path Coefficients, $t$ and Determination Coefficient

\begin{tabular}{|c|c|c|c|c|c|c|}
\hline \multirow[b]{2}{*}{$\begin{array}{l}\text { Predictive } \\
\text { Variable }\end{array}$} & \multicolumn{3}{|c|}{ Psychological Capital } & \multicolumn{3}{|c|}{ Intentional Organizational Forgetting } \\
\hline & $\begin{array}{c}\text { Path } \\
\text { Coefficient }(\beta)\end{array}$ & t-Statistics & $\begin{array}{c}\text { Total } \\
\text { Determination } \\
\text { Coefficient } \\
\left(\mathrm{R}^{2}\right)\end{array}$ & $\begin{array}{c}\text { Path } \\
\text { Coefficient }(\beta)\end{array}$ & t-Statistics & $\begin{array}{c}\text { Total } \\
\text { Determination } \\
\text { Coefficient } \\
\left(\mathrm{R}^{2}\right)\end{array}$ \\
\hline $\begin{array}{l}\text { Authentic } \\
\text { Leadership }\end{array}$ & 0.63 & $6.71 * *$ & 0.40 & 0.52 & $5.20 * *$ & \\
\hline $\begin{array}{l}\text { Psychologic } \\
\text { al Capital }\end{array}$ & & & & 0.46 & $4.36^{* *}$ & 0.53 \\
\hline
\end{tabular}

Coefficient of multiple determination value $\left(\mathrm{R}^{2}\right)$ indicates that the variables of authentic leadership and psychological capital can totally predict $53 \%$ of changes of the variable of organizational forgetting. Also, the variable of authentic leadership predicts $40 \%$ of changes of the variable of psychological capital.

\section{Discussion and Conclusion}

The present research has been conducted based on determining the role of authentic leadership in intentional organizational forgetting according to the staffs' psychological capital. The statistical population of the research includes all the staffs of National Oil Products Distribution Company of Sistanan \& Baluchestan Province. Findings of the research indicate that fitting indices are in a desirable status for confirmatory factor analysis models for all the latent variables. The results of testing the hypotheses show that authentic leadership has positive, direct, and significant effect on intentional organizational forgetting (the first hypothesis). The review of literature of the research indicates that previous studies which were based on experimental data have not tested the effects of authentic leadership on intentional organizational forgetting; hence, we cannot directly compare the results of those studies with other ones. So far no research has dealt with the effects of authentic leadership on intentional organizational forgetting; however, in some studies, the relationship between other leadership styles such as transformational leadership, transactional leadership, pragmatic leadership, and intentional organizational forgetting has been studied and the positive relationships among them have been approved. To this end, it can be said that the results of this research are indirectly consistent with the studies by TaghvaiYazdi (2015), Azizinejad et al. (2014), Moshabaki et al. (2011), and Moshabaki and Rabieh (2007).

In the relationship between authentic leadership with other similar management theories, authentic leadership has been raised as a complement to other ethical leadership and transformational leadership. Authentic leaders are not necessarily transformational, 
charismatic, or idealist. Moreover, authentic leadership is not synonymous with transformational leadership, charismatic, or idealist, but at the same time, transformational, charismatic, or idealist leadership can also be authentic. Similarly, Lloyd-Walker and Walker (2011) reported that authentic leadership is a combination of transformational leadership and ethical leadership and/or can be as the flow of increasing ethical leadership competencies to create transformational leadership.

The results of testing the second hypothesis show that psychological capital has a positive, direct, and significant effect on intentional organizational forgetting. The results of testing the third hypothesis indicate that authentic leadership has a positive, direct, and significant effect on psychological capital of the staffs. The staffs who are led by authentic leaders have more psychological capital and this encourages their psychological resource to be more creative. The results and findings of this hypothesis conform to the findings of Wang et al (2014), Rego et al. (2012), Clapp-Smith et al. (2009), and Yammarino et al. (2008). Also, the results of testing hypothesis four show that psychological capital as a mediator variable is partly effective on the relationship between authentic leadership and intentional organizational forgetting. The results of this research cause attention of managers of National Oil Products Distribution Company on this point that intentional organizational forgetting is a very important factor which allows for new methods through unlearning the existing methods and cause development of the organization and this occurs better when leaders of the organization can actively manage their organization; so that through this they prevent incorrect methods and knowledge which affects competitiveness of the organization which is harmful for the organization itself. This research has studied the relationship between authentic leadership and intentional organizational forgetting and psychological capital. It is suggested that in future research, this theory and other job attitudes be studied so that the importance of this theory becomes more and more obvious.

\section{References}

Algera, P. M., \& Lips-Wiersma, M. (2012). Radical authentic leadership: Co-creating the conditions under which all members of the organization can be authentic. The Leadership Quarterly, 23(1), 118-131.

Alok, K. (2014). Authentic leadership and psychological ownership: Investigation of interrelations. Leadership \& Organization Development Journal, 35(4), 266-285.

Avey, J. B., Patera, J. L., \& West, B. J. (2006). The implications of positive psychological capital on employee absenteeism. Journal of Leadership \& Organizational Studies, 13(2), 42-60.

Avolio, B. J., Gardner, W. L., Walumbwa, F. O., Luthans, F., \& May, D. R. (2004). Unlocking the mask: A look at the process by which authentic leaders impact follower attitudes and behaviors. The Leadership Quarterly, 15(6), 801-823.

Avolio, B. J., \& Gardner, W. L. (2005) .Authentic leadership development: Getting to the root of positive forms of leadership. The Leadership Quarterly, 16(3), 315-338.

Azizinejad, B., Jenabadi, H., \& Moradzadeh, A. B. (2011). Design model of leadership style on organizational forgetting and organizational performance using structural equation modeling. Public Management Research, 7(25), 75-96.

Baron, R., \& Kenny, D. A. (1986). The moderator-mediator variable distinction in social psychological research: Conceptual, strategic, and statistical considerations. Journal of Personality \& Social Psychology, 51,1173-1182.

Brown, M. E., \& Trevino, L. K. (2006) .Ethical leadership: A review and future directions. The Leadership Quarterly, 17(6), 596-616.

Clapp-Smith, R., Vogelgesang, G., \& Avey, J. B. (2009). Authentic leadership and positive psychological capital: The mediating role of trust at the group level of analysis. Organizational Studies, 15(3), 227-240.

Conklin, J. (2001). Designing organization memory. Retrieved from WWW.gdss.com. 
Diddams, M., \& Chang, G. C. (2012). Only human: Exploring the nature of weakness in authentic leadership. The Leadership Quarterly, 23(3), 593-603.

Fernandez, V., \& Sun, A. (2009). Organizational forgetting and its causes: An empirical research. Journal of Organizational Change Management, 22(6), 620-634.

Furmanczyk, J. (2010). The cross-cultural leadership aspect. Journal of Intercultural Management, 2(2), 67-82.

Gardner, W. L., Cogliser, C. C., Davis, K. M., \& Dickens, M. P. (2011). Authentic leadership: A review of the literature and research agenda. The Leadership Quarterly, 22(6), 1120-1145.

Hedberg, B. (1981). How organizations learn and unlearn .In W. Starbuck \& P. Nystorm (Eds.), Handbook of organizational design: Adapting organizations to their environments (pp. 3-27). Oxford: Oxford University Press.

Hinojosa, A. S., McCauley, K. D., Randolph-Seng. B., William, L., \& Gardner, W. L. (2014). Leader and follower attachment styles: Implications for authentic leader-follower relationships. The Leadership Quarterly, 25(3), 595-610.

Hodges, T. D. (2010). An experimental study of the impact of psychological capital on performance, engagement, and the contagion effect (Unpublished doctoral dissertation). Dissertations and Theses from the College of Business Administration, University of Nebraska Lincoln, School principals.

Hsiao, H. C., \& Chang, J. C. (2011). The role of organizational learning in transformational leadership and organizational innovation. Asia Pacific Education Review, 12(4), 621-631.

Joo, B. K., \& Nimon, K. (2014). Two of a kind? A canonical correlational study of transformational leadership and authentic leadership. European Journal of Training \& Development, 38(6), 570-587.

Kara, D., Uysal, M., Sirgy, M. J., \& Lee, G. (2013). The effects of leadership style on employee well-being in hospitality. International Journal of Hospitality Management, 34, 9-18.

Laschingera, H. S., \& Fida, R. (2014). New nurses burnout and workplace wellbeing: The influence of authentic leadership and psychological capital. Burnout Research, 1(1), 19-28.

Laschinger, H. K., \& Fida, R. (2014). A time-lagged analysis of the effect of authentic leadership on workplace bullying, burnout, and occupational turnover intentions. European Journal of Work \& Organizational Psychology, 23(5), 739-753.

Lloyd- Walker, B., \& Walker, D., (2011). Authentic leadership for $21^{\text {st }}$ century project delivery. International Journal of Project Management, 29, 383-395.

Luthans, F. (2002). The need for and meaning of positive organizational behavior. Journal of Organizational Behavior, 23(6), $695-706$.

Luthans, F., Avolio B. J., Avey, J. B., \& Norman, S. M. (2007). Positive psychological capital: Measurement and relationship with performance and satisfaction. Personnel Psychology, 60, 541-572.

Martin De Holan, P., \& Philips, N. (2003). Organizational forgetting. In M. Easterby-Smith \& M. A. Lyles (Eds.), The Blackwell handbook of organizational learning and knowledge management (pp. 393-409). Malden, MA: Blackwell.

Martin De Holan, P., Phillips, N. \& Lawrence, T. B. (2004). Managing organizational forgetting. MIT Sloan Management Review, 45(2), 44-51.

Moshabaki, A., AndalibArdakani, N., \& AndalibArdakani, D. (2011). The impact of leadership styles on purposeful forgetting: A new approach in knowledge management. Health Management, 14(44), 41-55.

Moshabaki, A., \& Rabieh, M. (2007). Organizational forgetting (strategic): Elixir competitiveness of the organization. Journal of Science Teacher, 13(4), 193-218.

Neider, L. L., \& Schriesheim, C. A. (2011). The authentic leadership inventory (ALI): Development and empirical tests. The Leadership Quarterly, 22(6), 1146-1164.

Peterson, S. J., Walumbwa, F. O., Avolio, B. J., \& Hannah, S. T. (2012). The relationship between authentic leadership and follower job performance: The mediating role of follower positivity in extreme contexts. Leadership Quarterly, 23(3), 502516.

Rego, A., Sousa, F., Marques, C., \& Pina e Cunha, M. (2012). Authentic leadership promoting employees’ psychological capital and creativity. Journal of Business Research, 65(3), 429-437.

Seligman, M. E. P. (1998). Learned Optimism. New York: Pocket Books.

Snyder, C. R., Irving, L., \& Anderson, J. (1991). Hope and health: Measuring the will and the ways. In C. R. Snyder \& D. R. Forsyth (Eds.), Handbook of social and clinical psychology (pp. 285-305). Elmsford, NY: Pergamon.

Stoten, D. W. (2014). Authentic leadership in English education: What do college teachers tell us? International Journal of Educational Management, 28(5), 510-522. 
TaghvaiYazdi, M. (2015). The relationship between transformational leadership style and organizational learning with organizational forgetting. Paper presented at the International Conference on Management, Economics, and Financial Systems, Dubai, Pendar Andish Rahpou Co.

Toor, S., \& Ofori, G. (2007). Leadership for future construction industry: Agenda for authentic Leadership. International Journal of Project Management, 26(6), 620-630.

Waite, R., Mckinney, N., Glasgow, M. S., \& Meloy, F. A. (2014). The embodiment of authentic leadership. Journal of Professional Nursing, 30(4), 282-291.

Walumbwa, F. O., Avolio, B. J., Gardner, W. L., Wernsing, T. S., \& Peterson, S. J. (2008). Authentic leadership: Development and validation of a theory-based measure. Journal of Management, 34(1), 89-126.

Wang, H., Sui, Y., Luthans, F., Wang, D., \& Wu, Y. (2014). Impact of authentic leadership on performance: Role of followers' positive psychological capital and relational processes. Journal of Organizational Behavior, 35(1), 5-21.

Wong, C. A., \& Laschinger, H. K. S. (2012). Authentic leadership, performance and job satisfaction: The mediating role of empowerment. Journal of Advanced Nursing, 69(4), 947-959.

Yammarino, F. J., Dionne, S. D., Schriesheim, C. A., \& Dansereau, F. (2008). Authentic leadership and positive organizational behavior: A meso, multi-level perspective. The Leadership Quarterly, 19(6), 693-707.

Zeng, J., \& Chen, C. (2010). The relationship between intentional organizational forgetting and organizational innovation: The mediating effect of organizational learning capability. China: School of Business Administration South China University of Technology Guangzhou. 